\title{
Gazzâlî’nin Eleştiriye Yaklaşımı ve Mezheb İmâmlarına Yönelik Eleştiri Üslûbu*
}

\section{Al-Ghazali's Approach To Criticism And His Criticism Style Towards The Madhhab Imams}

\author{
Sadrettin Buğda a, ** \\ ${ }^{a}$ Dr. Öğr. Üyesi, Muş Alparslan Üniversitesi, İslami İlimler Fakültesi, İslam Hukuku Anabilim Dalı, Temel İslami İlimler Bölümü, Muş/Türkiye. \\ ORCID: 0000-0002-6135-8570
}

\section{MAKALE BİLGİSİ \\ Makale Geçmişi: \\ Başvuru tarihi: 30 Mart 2021 \\ Düzeltme tarihi: 14 Mayıs 2021 \\ Kabul tarihi: 21 Mayıs 2021}

\section{Anahtar Kelimeler:}

F1k1h,

İslâm hukuku,

Eleştiri,

Gazzâlî,

Mezhep İmamlarına eleştiri
ÖZ

Şer'î delillerin büyük bir kısmının sübût ve delâlet bakımından zannî olmasının yanında fikhî meselelerin çözümünde kıyas gibi istidlâlî yöntemlerin çokça kullanılmış olması, fikhî mezhepler arasında ihtilaf ve eleştiri geleneğinin yerleşmesine yol açmıştır. Fıkhî mezhepler arasındaki eleştiri, mezheplerin teşekkülüyle başlayıp günümüze kadar devam etmiştir. Mezhep imamları, kurucu olmaları hasebiyle kendilerine mensup fakîhlere nazaran eleştirilerden daha fazla pay almışlardır. Başta kurucu imamlar olmak üzere her müçtehid ve fakîh, yaptığı istinbât ve içtihatta doğru gördüğünü savunmuş, muhalif davrananları da eleştirmiştir. Gazzâlî (öl. 505/1111) de kimi saiklerden ötürü bazı mezhepleri ve uygulamalarını eleştirmiştir. Bu çalışmada genel anlamda Gazzâlı’’nin eleştiri üslûbu özelde ise hayatının ilk dönemlerdeki mezhep imamlarına yönelik eleştiri üslubu ile daha sonraki eleştiri üslubunun keyfiyeti ele alınıp değerlendirmelerde bulunulmuştur.

\section{A B S T R A C T}

In addition to the fact that a large part of the Sharii dalils' certainty and guidance is zanni, the frequent use of inference methods like qiyas for the solution of fiqh issues has been the reason for the ikhtilaf and criticism among the fiqhi madhhabs/sects. Criticism among the fiqhi madhhabs/sects started with the formation of the madhhabs and have continued so far. The imams of madhhabs have been exposed to criticism much more than the faqihs who followed their madhhabs as they were the founders. All mujtahids and faqihs, especially the founding imams, defended their righteousness in their istinbat and ijtihad and criticized those who acted as mukhalifs. Al-Ghazali (d. 505/1111) also criticized some madhhabs/sects and their practices in his works for some reasons. In this study, the quality of criticism style of Ghazali in general, and his criticism style towards the madhhab imams in the first periods of his life and the nature of his later criticism style in particular were dealt with and evaluated.

\section{Keywords:}

Fiqh,

Islamic jurisprudence,

Criticism,

Al-Ghazali,

Criticism of the imams of madhhabs ise zannî olup içtihada açıktır. Zanna dayalı nassların içtihada açık olması nedeniyle- yorumlanması hususunda farklı yaklaşımlar sergilenmiştir. Bunun sonucunda farklı mezhepler ortaya çıkmış ve her mezhebe mensub âlimler, kendi mezhebini savunmuş ve hatalı bulduğu meselelerde karşıt mezhepleri eleştirmiştir.

İslâm ilim geleneğinde hakikatin tespit ve izharının hayati önem arz ettiği bilinen bir gerçektir. İslâm ulemâsı, inandıkları hakikati savunma ve aksini iddia edeni eleştirme

* Bu çalışma, 7 Aralık 2020 tarihinde Muş Alparslan Üniversitesi İslami İlimler Fakültesinde düzenlenen İslam Düşüncesinde Eleştiri Kültürü ve Tahammül Ahlâkı II (Klasik Dönem- M. VII.- XII. Yüzyıllar) Sempozyumunda sunulan bildirinin geliştirilmiş halidir.

** Sorumlu yazar/Corresponding author.

e-posta: s.bugda@alparslan.edu.tr 
hususunda gayret içinde olmuşlardır. $\mathrm{Bu}$ bağlamda âlimlerin bir mezhebi doğru ve isabetli bulup savunması ve karşıt görüş sahiplerine eleştiride bulunmasının yadırganacak bir davranış olmadığını ifade etmek gerekir. İlmî mirastaki hilâf literatürü ve reddiye geleneği bu gerçeğin göstergelerinden biridir. Dolayısıyla mezheb mensubu âlimler, çoğu meselelerde bağlı bulunduğu mezhebi isabetli bulmuş; muhalif gördüğü mezheb ve kişileri de eleştirmiştir. Hakikatin tespit ve kabulüne ciddi anlamda ehemmiyet veren ve bu bağlamda yanlış gördüğü düşüncenin reddi hususunda tereddüt etmeyen Gazzâlî de bunlardan biridir.

Gazzâlî, hakikatin ortaya çıkmasındaki rolüne binaen eleştiriyi önemsemektedir. Onun eleştiriye verdiği önemli göstergelerden biri el-Muntahal fi'l-cedel, adlı eseri te'lîf etmesidir. Ayrıca Gazzâlî'nin Şifâu'l-ğalîl fi beyâni'şşubehi ve'l-muhîli ve mesâliki't-ta 'lîl ve Tahsînu'l-meâhiz gibi eserlerini cedel yöntemiyle te'lîf etmesi de onun eleştiriye ve eleştirel düşünme yöntemine olumlu baktığının bir göstergesidir.

Eleştiri üslubu, eleştiri konusu gibi hususlarda günümüz İslâmî düşüncenin oluşumuna yönelik en ciddi katkıyı sağlayabilecek kişilerden biri, sadece yaşadığı çağı değil, kendi döneminden günümüze kadar İslâmî düşüncenin teşekkülünde önemli bir yer tutan ve İslâmî disiplinlerin her birinde yetkin olan Gazzâlî'dir. Onun eleştiri yaklaşımı ve eleştiri üslubuna yönelik geliştirdiği ilkeler yaşadığımız çağda hem bilim adamlarına hem de halka yönelik pek çok ilke sunmaktadır. Dolayısıyla Gazzâlî’nin eleştiri konusundaki görüşleri etraflıca araştırıp günümüz insanıyla buluşturmak önemli bir husustur. Söz konusu öneme binaen Gazzâlî'nin eleştiri düşüncesini ve eleştiri için tayin ettiği kriterleri alanda çalışma yapmak isteyenlere sunma gayesi, çalışmanın yapılmasının temel amili olmuştur. Ayrıca bu çalışma, Gazzâlı̂’nin usûl eserlerinin yanı sıra diğer eserlerini de esas alarak onun imamlara yönelik eleştiri üslûbunu ortaya koymayı da hedeflemektedir.

\section{2. İslâm'da Eleştiri Kültürü}

İslâm, ahlakî nitelik taşıma kaydıyla fikir ve düşüncelerini ifade etme hususunda insanlara geniş bir özgürlük alanı açmıştır (Muhammed Sâdık Afîfî, 1400/1980: 91-93). Dolayısıyla İslâm'a göre bireyler, -tenkit adabına riayet ederek- kişilerin yaptıkları hatalardan dolayı onları eleştirebilir (Afîfî, 1400/1980: 93. Eleştiri adabı için ayrıca

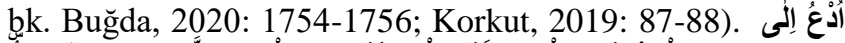

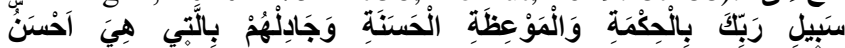
"Rabbinin yoluna hikmetle, güzel ögütle çağır ve onlarla en güzel şekilde mücadele et" (en-Nahl 16/125) ayeti, söz konusu meselenin açık bir delili olarak zikredilebilir. Zira mücadelenin olduğu yerde -cedelin tabiatı gereği- eleştiri de elbette meydana gelmektedir. Ayrıca "Mümin, müminin aynasıdır" (Ebû Dâvûd, "Edeb" 56; Beyhakî, 1414/1994: No. 16458) anlamındaki hadisin de bunun bir göstergesi olduğu söylenebilir. Zira Mümin birey, hata yapan kişilerin -ayna misali- hatalarını kendilerine göstererek uyarıda bulunur. Bununla birlikte İslâm, karşıdaki insanın şahsiyetini zedeleyebilecek eleştiri türünü de yasaklamıştır (Gazzâlî, ts.a: II/182.). Buna bağlı olarak şunu söylemek mümkündür: İslâm, nesnel ilkelere haiz olup sağlam temeller üzerine oturtulmuş eleştiriyi teşvik etmiş; ahlâkî ve tutarlılı̆̆ı olmayan, hakîkatin ortaya konulması gayesiyle yapılmayan eleştiriyi de reddetmiştir.

İslâm ilim geleneğinde eleştiri kültürünün, İslâm'ın doğuşuyla beraber söz konusu olduğunu söylemek mümkündür (Bilgin, 2019: 48). Emr-i bi'l-maruf ve nehy-i ani'l-münkere delâlet eden ayetler başta olmak üzere Kur'ân-1 Kerîm'de birçok ayet, İslâm'da eleştiri kültürünün ilk dönemden beri var olduğunu göstermektedir. Yukarıda zikredilen "Onlarla en güzel şekilde mücadele et" ayeti

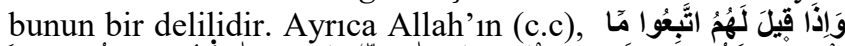

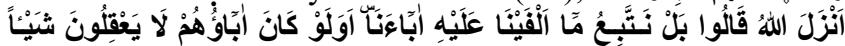

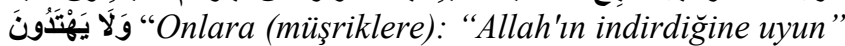
denildiği zaman, "Hayır! Biz, atalarımızı üzerinde bulduğumuz yola uyarlz» derler. Ya ataları bir şey akledemeyen, doğruyu da bulmayan idiyseler" (el-Bakara 2/170) bu ayetle Kur'ân-1 Kerîm'e tabi olmayanları eleştirmesi, İslâm'ın doğuşuyla beraber İslâm'da eleştirinin var olduğunun örneğidir. Birçok hadis de eleştiriye delâlet etmektedir. Örneğin ما بال أقوام "topluluğa ne oluyor"1 şeklinde varid olan hadislerin tamamı, Peygamber'in (s.a.v.) muhâtablarına yaptığı eleştirileri göstermektedir. Şu hadis de Peygamber'in (s.a.v.) bazı sahabilere yaptığ eleştirilerden biridir: "Şöyle şöyle diyen sizler misiniz? Vallahi sizden daha çok Allah'tan korkan ve O'na karşı daha çok takva sahibi olan benim. Bununla birlikte ben bazen oruç tutar, bazen iftar ederim. Hem namaz klar hem de uyurum. Kadınlarla da evlenirim. Benim sünnetimden yüz çeviren benden değildir" (Buhârî, "Nikâh" 1; Müslim, "Nikâh" 1.)

Hz. Ebû Bekir (r.a.) halife seçildiğinde: "Şayet iyilikte bulunduysam (doğru hareket ettiysem) bana yardım edin! Kötülük yaptıysam (doğru yoldan saptıysam) beni düzeltin!" (Ebû Dâvûd, 1414/1993: 56) şeklinde sarf ettiği sözü, sahabe dönemindeki eleştiri kültürünün önemini açıkça ortaya koymaktadır. Görüldüğü gibi Hz. Ebû Bekir (r.a.), yanlış yaptığında sahabe tarafindan kendisinin eleştirilmesini talep etmektedir. Halifenin bu anlayışı, İslâm kültüründe eleştirinin önemini ortaya koymaktadır. Zira eleştiri, doğrunun ortaya çıkması ve hakkın zayi olmaması açısından önemli bir etkendir.

Kureyşli kadının, Hz. Ömer'e (r.a.) gösterdiği tepki de dönemin eleştiri kültürünün bir yansımasıdır. Hz. Ömer'in (r.a.), kadınların mehirlerini üst seviye olarak 480 dirhemle sınırlı tutma isteğine karşı Kureyşli bir kadın: "Buna hakkın yoktur ey Ömer" diye tepki gösterir. Hz. Ömer (r.a.) niçin

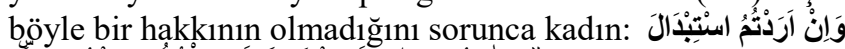
'Bir eşi bırakıp yerine başka bir eş almak isterseniz, birincisine yüklerce altın vermiş olsanız bile ondan bir şey almayın" (en-Nisâ 4/20) ayetini görüşüne delil olarak ileri sürer. Bunun üzerine Hz. Ömer (r.a.), “Allah'ım beni affet, bütün insanlar Ömer'den daha iyi biliyor" şeklinde Allah’tan af diler (Beyhakî, 1414/1994: No. 14336). Hz. Ömer ile kadın arasında geçen söz konusu diyalog, hakkın ortaya çıkmasında eleştirinin önemini ortaya koyduğu gibi başta

Örnek için bk. Ebû Abdullâh Muhammed b. İsmâîl el-Buhârî, Câmi 'u's-Sahîh. thk. Muhammed Zuheyr b. Nâsır (b.y.: Dâru Tavki'n-Ncât, 1422/2001) "Selât" 69 (No. 456), "Ezân" 92 (750), "Cuma” 217 (No. 6101); Beyhakî, es-Sünenü'l-Kübrâ, 2/172 (No. 2786), 2/282 (No.3351), 2/453 (No. 4169), 5/338 (No. 10627), 6/170 (No. 11733), 7/132 (No. 13534), 7/322 (No. 14675), 2/360 (No. 14893), 9/77 (No. 17868), 10/337 (No. 21513). 
devlet başkanı olmak üzere insanların eleştiri karşısındaki tutumlarının nasıl olması gerektiği hususunda da önemli bir örnektir. Hz. Ömer (r.a.), Mısır valisi Amr İbnü'l-Âs'ın oğlunun haksız yere bir Kıptiye vurması ve Kıptinin Hz. Ömer'e (r.a.) şikâyette bulunmasından sonra Amr İbnü'lÂs'a: "Ey Amr! Annelerinin hür olarak doğurduğu insanları ne zamandan beri köleleştirdiniz?" sözü, yapıcı eleştirinin en önemli örneklerinden biri olarak kabul edilebilir (Alî b. Husâmuddîn el-Hindî, 1401/1981: 12/661). Mezkûr olay, eleştirinin haksızlıkların önlenmesinde ne kadar önemli olduğunu göstermektedir. $\mathrm{Bu}$ tarz eleştirilerin, makam sahipleri ve yakınlarının kendilerine verilen imtiyazı istismar ederek başkalarına yapacakları haksızlıkları önlemede önemli olduğu söylenebilir.

\section{Gazzâlî’nin Eleştiriye Bakışı}

Gazzâlı’’nin fikıh usûlü, mantık, felsefe, tasavvuf gibi birçok alanda geniş bilgi birikimine sahip olması, onun eleştiriye yönelik tavrını farklı disiplinlerde ve alanlarda zuhur etmesini beraberinde getirmiştir. $\mathrm{Bu}$ bağlamda Gazzâlı’'nin birçok disiplinde yetkin olması ve her disiplinin kendisine has normatif değerler çerçevesinde ele alıp tenkide tabi tutması, onun eleştiri düşüncesinin çeşitli düzlemlerde ele alınmasını zorunlu hale getirmektedir.

Gazzâlı’’nin ele aldığı disiplinleri geniş bir tetkike tabi tutarak, kendine has bir metotla ortaya koyduğu eserlere bakıldığında onun yazılan bazı eser ve ileri sürülen düşüncelere eleştirel bir tavır sergilediği görülmektedir. Buna bağlı olarak Gazzâlı̂’nin hakikati elde etme çabasıyla yapılan eleştiriye olumlu baktı̆ı̆ını ifade etmek mümkündür (Gazzâlî, 1423/2004: 308). Onun cedel disiplinine dair elMuntahal fi'l-cedel adlı bir eser kaleme alması ve cedelin faydalarından bahsetmesi onun eleştiriye olumlu baktığının bir göstergesi olduğu söylenebilir. Bunun yanı sıra "vacip, mendûb ve vacip veya mendûb olmamakla birlikte yararlı olan münazara" şeklinde münazarayı kısımlara ayırması da bunu teyit etmektedir (Gazzâlî, 1417/1997: 2/422). Zira eleştiri, cedel ve münâzaranın karakteristik özeliğidir. Gazzâlî’nin usûl alanında yazdığı Şifâu'l-ğalîl fi beyâni'şşubehi ve'l-muhîli ve mesâliki't-ta 'lîl adlı eserini cedel yöntemiyle kaleme alması da onun ilmî meselelerde yapılan eleştiriye olumlu baktığının göstergesidir. Bununla birlikte Gazzâlî, her eleştiri türünü de kabul etmemektedir (Gazzâlî, ts.a: I/45). Gazzâlî, eleştirinin kabulü ve reddi hususunda; eleştirinin usûlü, adabı, mahiyeti, amacı, eleştiride bulunan kişinin yetkinliği gibi eleştirinin farklı yönlerini dikkate alarak tavır ortaya koymaktadır.

Gazzâlî, eleştiride bulunan kişinin muhatabının kişiliğini zedeleyecek ve izzet-i nefsine halel getirecek durumlardan sakınmasını ve mümkün oldukça baş başa kaldıklarında ona eleştiride bulunması tavsiyesinde bulunur (Gazzâlî, 1431/2010: 136). Gazzâlî'ye göre burada dikkat edilmesi gereken bir diğer husus da eleştiride bulunanın, toplum içinde muhatabının onurunu kıracak davranışlardan uzak durmasıdır. Aksi takdirde yapılan eleştiri, yarardan ziyade zarar getirir. Zira onuru kırılan kişi, o an kendisine hâkim olan psikolojik durumdan dolayı hakkı kabul etmeyerek kendi düşüncesinin doğruluğunu savunmaya yönelebilir. Gazzâlî, aslında burada iki hususa dikkat çekmektedir. Birincisi tahammülsüzlüğe ve insafsızlığa sebebiyet veren, psikolojik durumu sarsan eleştiriden sakınılmasıdır. İkincisi ise eleştiride bulunan kişide oluşabilen kibir ve enaniyet duygularının İlâhî rızanın önüne geçme tehlikesidir. Her iki husus da eleştirinin amacına ters düşmektedir. Gazzâlî, İhyâu 'ulûmi'd-dîn adlı eserinde konu hakkında görüşlerini şöyle serd etmektedir: "Yapılan tartısmanın büyükler huzurunda ve mahfillerde/halk arasinda olmaktan ziyade, tenha yerlerde yapllmast tercih edilmelidir. Zira tenha yerler; hakikatin künhüne varılmasına, zihin ve algının açık olmasina, (meselenin) kavranilmasina daha elverişlidir. Halk arasinda yapılan tartışmalar, riya tehlikesine neden olur ve hakl haksiz tartışmalarda üstün gelme hirsl uyandırır..." (Gazzâlî, ts.a: I/44).

Gazzâlî, eleştiride hakkı izhâr etme arzusunu merkeze almaktadır. Ona göre eleştiride güdülen temel amaç, hakkı ortaya çıkarma ve doğruyu tespit etme mefkûresi olmalıdır. $\mathrm{Bu}$ bağlamda hak olan, kimin diliyle meydana geliyorsa gelsin mutlaka kabul edilmelidir. Gazzâlî, söz konusu meseleyle ilgili "Arkadaşların azarlamasından sakınmak pahasına hak terkedilemez" şeklindeki ilkeyi ileri sürerek hakkı kabul etmede hiç kimsenin kınamasından çekinmemek gerektiğini belirtir (Gazzâlî, 1390/1971: 633; Karasu, 2019: 451; Gülaçar, 2019: 505). Gazzâlî, genelde hak arayışı içinde olanlara özelde ise dostlarına bu hususta yapılan eleştirileri dikkate almamalarını, mutaassıpların yaptıkları eleştirilere dikkat etmemelerini ve haksız eleştirilere karşı sabırlı olmalarını tavsiye eder (Gazzâlî, ts.a: I/44). Gazzâlî hakkın izhâr ve kabulünü yitik mala benzetmektedir. O, kişinin hakkı arama hususunda, kaybettiği malını arayan kimseler gibi olması gerektiğini ifade eder. Nasıl ki mal sahibi malı bulanın fikir ve düşüncesine, mezhep ve meşrebine bakmaksızın kendisinden malını teslim alıyorsa; hak peşinde olan kimsenin de hakkın kimler tarafından ortaya konduğuna bakmaksızın onu kabul etmelidir. Gazzâlî, bu hususta sahabeden birçok örnek vererek olayı somutlaştırmaya çalışmaktadır. Onun getirdiği örneklerden biri de mehrin üst seviyesini belirleme konusunda Hz. Ömer (r.a.) ile Kureyşli kadın arasında geçen diyalogdur. Söz konusu diyalogda Hz. Ömer (r.a.), kendisini eleştiren kadını kastederek "Bir erkek yanıldı, bir kadın doğruyu buldu." diyerek kendisini eleştiren kadının sözünü kabul ettiği aktarılmaktadır (Gazzâlı̂, ts.a: I/44).

Gazzâlî’nin eleştiride dikkat çektiği hususlardan biri de muhatabın iddiasını en ince noktasına kadar kavrama ve geniş bilgiye vakıf olma ilkesidir. Ona göre muhatabın ileri sürdüğ̈̈ gerekçelere, dayandığı temel ilkelere, kullandığ 1 kavramlara vakıf olamayan kişiler, muhataplarını eleştirmemelidir. Aynı şekilde eleştiride bulunan kişi, konu hakkındaki malumata hakkıyla vakıf olmalıdır (Konu için ayrica bk. Y1ldız, 2019: III/451). O, bunu hastalık metaforu üzerinden şu şekilde izah etmektedir: "Dinle! Yarar sağlayacak bir şeyi sana anlatacağım. Problemlere yönelik sorular, kalp rahatsılı̆ı̆ın tabibe arz etmek (gibidir). Verilen cevap ise hastalığı iyileştirme çabasıdır. Bil ki cahiller kalp hastalarıdır. Âlimler ise tabiplerdir (tabip gibidirler). Yetkin olmayan (konu hakkında bilgisi olmayan) âlim tedaviyi iyi yapamaz (konuya çözüm getiremez)” (Gazzâlî, 1431/2010: 135). Dolayısıyla eleştiride bulunan kişinin eleştirdiği düşüncenin arka planını oluşturan delillerin ne olduğuna ve delillerin zayıf yönlerine vakıf olmalı, kendisinin ileri sürdüğü delillere de hâkim olmalıdır ki eleştirinin bir yararı olsun. Gazzâlî bu hususu şu şekilde dile getirmektedir: "Anladım ki bir 
mezhebi anlamadan, künhüne vakıf olmadan onu reddetmek karanlığa taş atmak gibidir" (Gazzâlî, 1414/1991: 25)

Gazzâlî, eleştiride bulunan kişinin müctehid veya kendi görüşüyle fetva verebilecek seviyede olmasının şart olduğunu ileri sürmektedir. Ancak mezkûr seviyede olmayan kişilerin bağlı bulunduğu mezhebin imamına uygun şekilde eleștiride bulunması gerektiğini ifade etmektedir. Buna bağlı olarak şunu ifade etmek mümkündür: Gazzâlî'ye göre mukallid, yapılan tartışmada gelen soru ve eleştirilere mezhebin esas aldığı delillere dayanarak cevap vermelidir. O, mukallidin eleştiride mezheb imamının kabul etmediği delillerle cevap vermesini veya başka mezhep imamlarının görüşlerini delil getirerek muterize karşı koymasını doğru bulmamaktadır (Gazzâlî, ts.a: I/43). Dolayısıyla Gazzâlî’ye göre müçtehid veya kendi görüşüyle fetva verebilecek seviyede olmayan kişilerin bağlı bulundukları mezhebin temel kabulleri, ilkeleri ve yöntemi çerçevesinde eleştiriye girișebileceklerini söylemek mümkündür. Ona göre söz konusu kişilerin herhangi bir mezhebe bağlı kalmaksızın mezhebî konularda eleştiri yapmalarının doğru olmadığ söylenebilir. Bununla beraber Gazzâlî, mukallide tabi olduğu mezhebe yönelik eleştirilere sınırlı da olsa cevap verebilmeyi mümkün görerek inandığı şeyi savunma gibi bir erdemin -ki yukarıda bahsettiğimiz hakkın izharı ile ilintilidir- kişilerde gelişmesine de olanak sağlamaktadır.

Gazzâlî’ye göre eleştirinin birçok faydası bulunmaktadır. Bunlar şu şekilde özetlenebilir: Eleştiri, müçtehid katında tearuz eden iki delilden birinin tercihi hususunda müçtehide yardımcı olabilir. Hükmün menâtını tahkik etme hususunda da eleştirinin yararlı olduğu söylenebilir. Eleştiri, kişinin kendi doğru metoduna dikkat çekmek suretiyle hasmın takip ettiği metodun yanlışlığını ortaya koyarak hasmı daha tutarlı gördüğü metoda yönlendirmesinde de önemli bir etken olduğu ifade edilebilir. Eleştiri, zihin jimnastiğine ve kavrama kabiliyetinin gelişmesine neden olur. Bu vesileyle kişi, usûlî kuralları daha pratik bir şekilde algılayarak kullanabilir (Gazzâlî, 1417/1997: 2/422-423).

Gazzâlî’nin yukarıda zikredilen düşünceleri dikkate alındığında onun eleştiriye yaklaşımı hususunda şunu söylemek mümkündür: Gazzâlî’nin hakikatin bilgisine varmak için ilmî normlar esas alınarak ve ahlakî kurallara riayet edilerek yapılan eleştiriyi kabul ettiğini, toptan red ve kabulden uzak bir tavır sergilediği ifade edilebilir. $\mathrm{O}$, herhangi bir düşünce sistemini ve mezhep mensuplarını ayırt etmeden ve hakkın kimden geldiğine bakmadan hakkın kabullenilmesi ve aksi bir tutumun da reddedilmesi gerektiği şeklinde bir tavır ortaya koymuştur.

Gazzâlî, eleştirinin kendisinde çekememezliğe, kibir ve insanlara karşı üstünlük taslamaya, kine, gıybete, tezkiye-i nefse, tecessüse yani insanların gizli kusurlarını aramaya, ikiyüzlülüğe, riyaya ve psikolojik nedenlerden dolayı hakkı reddetmeye vesile olabilen kişilerin eleştiriye girişmemelerini tavsiye etmektedir (Gazzâlî, ts.a: I/45-48).

\section{Gazzâlî’nin Mezhep İmâmlarına Yönelik Eleştirileri}

İnsanların ilmî tekâmülden önce ile sonraki eleştiri üslûplarının ve cesaretlerinin farklılık arz ettiği bir hakikattir. Bunun yanı sıra ortam ve şartların da kişinin eleştiri üslûbu üzerinde etkisi olduğunu söylemek mümkündür. Hasmın eleştiri tarzı da eleştirinin dozu hususunda önemli bir etken olarak değerlendirilebilir. Gazzâlî'nin el-Menhûl adlı eserindeki mezheb imamlarına yönelik eleştiri üslûbu ile İhyâu 'ulûmi'd-Dîn ve elMustasfâ gibi daha sonra te'lîf ettiği eserlerindeki eleştiri üslûbu arasındaki fark dikkate alındığında mezkûr hususların Gazzâlî için de söz konusu olduğu ifade edilebilir (Gazzâlî, ts.b: 489-491). Gazzâlî, ilk te'lîf ettiği el-Menhûl adlı eserinde Ebû Hanife ve İmâm Mâlik'i eleştirirken kullandığ $\breve{g}_{1}$ ifade ve üslûp sertlik arz ederken; İhyâu 'ulumi'd-dîn gibi daha sonra kaleme aldığı eserlerde söz konusu sertliğin, yerini saygı ve değer ifade eden bir üslûba bıraktığı görülmektedir. Hatta bazı eserlerinde kișilerin, imamların dayandıkları delilleri ve ileri sürdükleri görüşleri zayıf ve yanlış olarak görüyorsa dahi hatayı imamlarda değil kendisinde aramaları ve bu hususta kişinin büyük imamlara karşı saygılı olması gerektiğini belirtir (Gazzâlî, 1438/2017: 65).

Yukarıda zikredildiği gibi Gazzâlî’nin el-Menhûl adlı eserinde mezheb imamlarına yönelik eleştirisi serttir. Gazzâlî, mezkûr eserinde İmâm Ebû Hanife'nin nebîzi necis saymama fikrini, köpeğin derisinin tabaklanmak yoluyla temizleneceğine dair görüşünü (Hanefî mezhebinin konu hakkındaki görüşü için bk. Cessâs, 1415/1994: I/140142; Aynî, 1420/2000: I/407) namaz tekbirinin Türkçe gibi başka bir dille de getirilebileceği fetvasını, iki secde arasındaki celseyi sünnet görmesini yani birinci secdeden sonra başını kaldırıp oturmadan ikinci secdeye gidilmesi yönündeki düşüncesini ileri sürerek Ebû Hanife'yi eleştirmektedir (Ebû Hanife'nin mesele hakkındaki görüşü için bk. Aynî, 1420/2000: II/248, 250). Gazzâlî, aynı zamanda nebîze dalan, köpeğin tabaklanmış derisini giyen, oturmadan iki secdeyi peş peşe yapan, başka bir dille tekbir getiren ve namazın sonunda selam yerine abdestini bozarak namazdan çıkan bir kişinin namazının Ebû Hanife'ye göre sahih olduğunu söylemektedir. Gazzâlî, Ebû Hanife'nin mezkûr fetvalarının yanı sıra oruç, zekât, ukûbât vb. konulardaki bazı içtihatlarında isabet etmediğini ifade ederek nispeten ağır bir şekilde Ebû Hanife'yi eleştirmektedir. Gazzâlî, aynı konu çerçevesinde Ebû Hanife'nin yalancı şahitlerin, birinin nikâhlı hanımının başka birinin hanımı olduğuna şahitlik etmeleri durumunda kâdının/hakimin, yanlış olarak kendi lehine şahitlik edilen kişinin hanımı olarak hüküm vermesi halinde, lehine hüküm verilen kişi bunun yalan olduğu bildiği halde bayanın kendisine helal ve ilk eşine haram olduğu yönündeki fetvasından ${ }^{2}$ dolayı da Ebû Hanife'yi benzer şekilde tenkîd etmektedir (Gazzâlî, ts.b: 500-503).

Gazzâlî, Ebû Hanife'nin bazı sahih hadisleri bırakıp zayıf hadislerle amel ettiğini dolayısıyla onun hadisleri iyi bilmediği şeklinde Ebû Hanife'yi eleştirmektedir. O, ayrıca Ebû Hanife'nin "ولو رماه بأبو قبيس" şeklinde ifade ettiği bir sözden hareketle Ebû Hanife'nin dile hâkim olmadığ1 tarzda bir iddiayı ileri sürerek onu eleştirmektedir (Gazzâlî, ts.b: 471). 
Gazzâlî, aynı eserinde benzer şekilde İmâm Mâlik'i de bazı görüşlerinden dolayı eleştirmektedir. O, İmâm Mâlik'in mesâlihi çokça kullanması, onu ümmetin üçte birini diğer üçte birinin maslahatı için öldürmeye, ta'zîrin gerektiği yerde adamı öldürmeye ve kanıt olmaksızın sadece töhmet ile adama celde cezasını uygulamaya cevâz vermesine sevk ettiğini belirterek İmâm Mâlik'i tenkîd etmektedir. Gazzâlî, ayrıca İmâm Mâlik'in Medine ehlinin amelini hadise öncelediği gerekçesiyle de onu eleştirmiştir (Gazzâlî, ts.b: 471).

Gazzâlî'nin el-Menhûl adlı eserindeki mezheb imamlarına yönelik eleştirilerinin sert oluşunun farklı nedenlerden kaynaklandığını söylemek mümkündür. Birincisi, Gazzâlî mezkûr eserde hocası İmâmü'l-Haremeyn el-Cüveynî'nin (öl. 478/1085) etkisinde kalarak imamlara yönelik fikirlerini ortaya koyduğu ifade edilebilir (Gazzâlî, ts.b: (tahkîk edenin notu), 490). Zira Cüveynî'nin mezheb imamlarına yönelik eleştirileri incelendiğinde arada azımsanmayacak bir benzerliğin olduğu görülmektedir. ${ }^{3}$ İkincisi, ilmî çevredeki taassub atmosferi, Gazzâlî'nin eleştirilerine neden olarak gösterilebilir. Dönemin ehl-i rey ve ehli hadis arasındaki tartışmalar, Ebü'l-Hasen elKerhî'nin (ö. 340/952) "Ebû Hanife'nin sözüne muhalif düşen hadislerin tamamı ya mensûhtur veya müevveldir" (Sen’ânî, 1405/1985: 17) ifadesi, Abdullâh İbn Mübârek'e (öl. 181/797) nispet edilen 'Ebû Hanife'nin sözünü reddeden kişiye kum tanecikleri kadar Allah'ın laneti üzerine olsun" (el-Haskefî, 1423/2002: 15) şiiri, Ebü’l-Yüsr el-Pezdevî’nin (öl. 493/1100) rükûa gitme ve kalkma esnasında ellerin kaldırılmasını gerekçe göstererek Hanefî birinin Şâfîi birine tabi olmasının caiz olmadığı fetvası (İbnü'l-Hümâm, 1405/1985: I/452) vb. taassubu ifade eden sözler, Gazzâlî’yi sert eleştiride bulunmaya sevk etmiş olabilir (Gazzâlî, ts.b: (tahkîk edenin notu), 489-490). Üçüncüsü, Gazzâlî’nin sert eleştirilerde bulunması ilmî ve fikrî tekâmülden önceki durumla ilgili olduğu, böyle bir durumun ise herkes için söz konusu olabileceği düşünülebilir. Yukarıda ifade edildiği gibi daha sonra kaleme aldığı eserlere bakıldığında mezheb imamlarına yönelik söylemlerinin değiştiği görülmektedir.

Gazzâlî’nin mezheb imamlarına yönelik eleştirel bir tavır sergilemesi sadece ona ve Cüveynî gibi Şafîi mezhebine mensup âlimlere ait bir tavır değildir. Yukarıda Kerhî’ye ve Abdullâh İbn Mübârek'e nispet edilen ifadelere bakıldığında bu âlimlerin de mensup oldukları mezheb imamını övdükleri, diğer mezheb imamlarını da yerdikleri anlaşılmaktadır. Mûsâ b. Zekeriyyâ el-Haskefî’nin (öl. 650/1253) "Birisi bizim ve diğer mezhepler hakkında soru sorsa mezhebimiz doğrudur; hatayı barındırma ihtimali de bulunmaktadır. Muhalifimizin mezhebi ise hatalıdır; doğruyu barındırma ihtimali de vardır" ifadesi de zımni olarak eleştiriyi barındırmaktadır (el-Haskefî, 1423/2002: 12).

Yukarıda da ifade edildiği gibi Gazzâlî’nin el-Menhûl adlı eserinden sonra te'lîf ettiği eserlere bakıldığında onun mezheb imamlarına yönelik farklı bir tutum içinde olduğu

Karşılaştırma için bk. İmâmü'l-Haremeyn Ebü'l-Meâlî Rüknüddîn Abdülmelik b. Abdillâh b. Yûsuf el-Cüveynî, el-Burhân fî Usûli'lFıkh, thk. Abdülazîm ed-Dîb (Mansûriyye, Dâru'l-Vefâ, 1418/1997) 2/748, 873-874; Davut Eşit, "Gazzâlî'nin Ebû Hanîfe Eleştirisi”, II. Türkiye Lisansüstü Calışmalar Kongresi Bildiriler Kitabı, ed. Ümit Güneş (İstanbul: Star Ajans Matbaacılık, 2013), 4/993-994. görülmektedir. O, her ne kadar mezkûr eserinde imamları eleştirse de hem bu eserinde hem de diğer eserlerinde imamların isimlerini zikrederken akabinde "Rahimehullah" veya "Radiyellahu anh" şeklinde duada bulunmaktadır. Gazzâlî, Ihyâu 'ulûmi'd-dîn adlı eserinde ahiret ilminden söz ederken mezheb imamları ve onların hallerini/bazı özeliklerini aktarır. O, fikıhî mezheb imamlarını Şâfîi, Mâlik, Ebû Hanife, Ahmed b. Hanbel (öl. 241/855) ve Süfyân es-Sevrî (öl. 161/778) şeklinde sırasıyla zikretmekte ve bu imamların fikıh ilminin reisleri/öncüleri olduğunu belirtmektedir (Gazzâlî, ts.a: I/24). Gazzâlî, mezkûr imamların âbid, zâhid, ahiret âlimleri ve insanların kendilerine muhtaç olduğu fikıh bilginleri şeklinde onların ortak özelliklerinden söz etmektedir (Gazzâlî, ts.a: I/24).

Gazzâlî, Ebû Hanife'den söz ederken onun âbid, zâhid, Allah'1 (c.c.) bilen, ondan korkan ve O'nun rizasını dileyen bir zat olduğunu söyler ve akabinde zikredilen hasletlere delâlet eden fiil ve tutumlarını, âlimlerin onun için ifade ettikleri söz ve kanaatlerini aktarır. O, Ebû Hanife'nin gecenin büyük bir kısmını hatta kimilerine göre gecenin tümünü ibadetle geçiren bir âbid, kendisine arz edilen görev ve dünyalık şeyleri reddeden bir zâhid, dinde mühim olan meselelerle meşgul bir zat olduğunu bildirir (Gazzâlî, ts.a: $\mathrm{I} / 28)$.

Gazzâlî, İmâm Mâlik için de benzer vasıflardan söz eder, özellikle onun dinî bilgilere verdiği önemi zikreder. O, İmâm Mâlik'in ilme verdiği öneminden söz ederken “ $O$, bir hadisi rivayet etmek istediğinde abdest alır, sakalını tarar, koku sürünür ve huşu içinde diz üstü oturduktan sonra rivayet ederdi" (Gazzâlî, ts.a: I/27) şeklinde onun bu konudaki hasletini dile getirir.

Gazzâlî, İmâm Şâfî̂’nin zâhid, âbid, cömert, dünya sevgisini taşımama gibi özeliklerinden uzunca bahsetmekte ve âlimlerin onun hakkındaki sözlerini aktarmaktadır (Gazzâlî, ts.a: I/24-26). Gazzâlî, el-Menhûl adlı eserinde Şâfiî’nin usûl ilmini en iyi bilen, bu alanda ilk eser te'lîf eden, şerî delilleri bir tertip dâhilinde ele alan, Nazzâm gibi icmâ' 1 inkâr etmeyen, Şiîler gibi âhâd hadisleri, Zâhirîler gibi kıyası reddetmeyen âlim olarak nitelemekte ve insanların İmâm Şâfî̀’ye tabi olmalarının gerekli olduğunu ifade etmektedir (Gazzâlî, ts.a: I/24). ${ }^{4}$ Gazzâlî söz konusu eserinde her ne kadar Şâfiî mezhebinin mutlak üstünlüğünden bahsetse de daha sonra te'lîf ettiği eserlerinde ise yeri geldikçe diğer mezheplerin hakkını teslim etmekte ve onların verdikleri fetvaları daha isabetli gördüğü yerlerde bu fetvaların daha uygun olduğunu belirtmekten de kaçınmamaktadır. Örneğin Gazzâlî, mehrini kocasına hibe eden kadının zifafa girmeden önce boşanması durumunda mehrini tekrar geri alma hakkı olup olmama hususundaki tartışmaları aktardıktan sonra şöyle söylemektedir: "Meselenin kaynağındaki/referansındaki müphemliğinden ve birden fazla tercihe açı olmasından Şâfîi'nin konu hakkındaki söylemleri farklı olmuştur. (Söz konusu meselede) Ebû Hanife'nin mezhebi daha iyi ve daha vasat/dengelidir " أحسن وأعدل". Şâfîînin mezhebî ise kıyasa

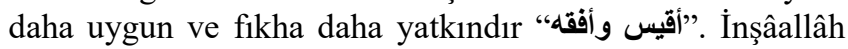

\footnotetext{
Gazzâlî'nin buradaki söylemleri, Cüveynî'nin ifadeleriyle benzerlik taşımaktadır. Dolayısıyla bu hususta da onun hocasından etkilendiğini söylenebilir. Karşılaştırma için bk. İmâmü'l-Haremeyn Ebü'l-Meâlî Rüknüddîn Abdülmelik b. Abdillâh b. Yûsuf el-Cüveynî, Ğlyâsü’ $l$ ümem fí't-tiyâsi'z-zulem, thk. Abdülazîm ed-Dîb (Mansûriyye, Dâru'lVefâ, 1418/1997) 295-298.
} 
her iki mezheb de sevaba uygun ve eşittirler" (Gazzâlî, ts.b: 504). Örnekte görüldüğü gibi Gazzâlî söz konusu meselede diğer mezhebin hakkını teslim ederek taassuptan uzak bir tavir sergilemektedir.

Gazzâlî, el-Menhûl adlı eserinde Ahmed b. Hanbel ve Süfyân es-Sevrî ile ilgili olumlu veya olumsuz herhangi bir şeyden söz etmezken Ihyâu 'ulûmi'd-dîn adlı eserinde ise onların iyi hasletlerinden bahsetmektedir. O, Ahmed b. Hanbel ve Süfyân es-Sevrî'ye tabi olanların az olduğunu özellikle Süfyân es-Sevrî'ye tabi olanların daha az olduğunu belirmekte ancak her iki imamın da haramdan kaçınmaları, dünyaya sırt çevirmeleri gibi takva ve zühd açısından daha meşhur olduğunu ifade etmektedir (Gazzâlî, ts.b: 504).

Netice itibariyle şunu ifade etmek mümkündür: Gazzâlî gençlik döneminde ve ilk te'lîf ettiği eserinde imamlara yönelik eleştirileri sert olsa da daha sonraki dönemlerde te'lîf ettiği eserlerinde imamlara yönelik olumlu tavır sergilemekte ve onların meziyetlerini anlatmaktadır. Gazzâlî, mezheb imamlarını sadece övmekle yetinmemekte hatta büyük imamların görüşleri kendisine ters düşen kişilere onları eleştirmekten kaçınmalarını ve kusuru kendilerinde aramalarını tavsiye etmektedir (Gazzâlî, 1438/2017: 65).

\section{Gazzâlî’ye Göre Mezhep İmâmlarının Görüşleri Ele Alınırken Dikkat Edilmesi Gereken Tavır}

Yukarıda ifade edildiği gibi Gazzâlî, hasmın izzet-i nefsine halel getirecek hiçbir eleştiriyi doğru görmemektedir. Ona göre onur kırıcı olan eleştiriler problem çözmekten ziyade sorun oluşturmaktadır. Söz konusu mezheb imamları olunca eleştiri üslûbu daha da önem arz etmektedir. Gazzâlî, bir kimsenin zâhir bir söze ve açık bir delile dayanarak büyük âlimlerden birinin görüşünün yanlış olduğunu düşünüyorsa ve bu gerekçeyle kabullenemiyorsa aceleci davranıp onu büyük âlimin görüşünü- inkâra kalkışmaması gerektiğini ifade eder. Gazzâlî mezkûr durumla ilgili iki seçenekten bahseder. Birincisi kişi, yüce mertebesine rağmen söz konusu açık delilin mezheb imamına (العالم الكبيز)/büyük âlim) gizli kaldığına hükmetmelidir. İkinci seçenek ise kendisinin vakıf olmadığı kapalı bir sirra mezheb imamın/büyük âlimin vakıf olduğunu kabul etmelidir (Gazzâlî, 1438/2017: 65). Gazzâlî, mukallid birisi mezheb imamının içtihadını zayıf bulduğunda mezheb imamını terk etmemesi ve onun bu konuyu daha iyi bildiğini ancak kendisinin sadece bir mukallid olduğu şeklinde bir tavır ortaya koyması gerektiğini belirtmektedir (Gazzâlî, ts.a: I/43). Ona göre müçtehid konumunda olmayan birinin başta kendi bağlı bulunduğu mezheb imamını olmak üzere imamları eleştirme hakkı yoktur (Gazzâlî, ts.a: I/43). Gazzâlî, eleştiride bulunanların imamların farklı fetvalarından hareketle bu imamların farkına varmadan çelişkiye düşmekle eleştirmemeleri gerektiğini vurgulamakta, imamları çelişkiye düşmekle itham edenleri ise kıt akıllı ve hayâsız olarak nitelendirmektedir (Gazzâlî, 1438/2017: 66; Y. Eşit, 2019: 135). Gazzâlî’nin mezkûr düşüncenin sebebi ise onun yapılan eleştirinin ilme ve bilgiye dayalı olması hususunda gösterdiği hassasiyet olduğunu söylemek mümkündür.

Gazzâlî, bir mezheb imamına tabi olan birinin diğer mezheb imamlarına karşı saygılı olması gerektiğini, zira diğer mezheb imamlarına karşı saygılı davranmayan ve onları ta' $n$ eden kişinin, farkına varmadan kendi imamına da saygısızlık yapmış olduğunu belirtir. Gazzâlî bunu şöyle açıklamaktadır: Şâfî̀'yi eleştiren ve ona dil uzatan kişi, kendi mezheb imamına dil uzatılmasına neden olmaktadır (Gazzâlî, 1438/2017: 69). Ona göre bir mezhebin bütün olarak düşünüldüğünde elbette eleştirilecek bazı yönleri olabilmektedir. Ancak bunların tespitinde ve ortaya konulmasında sayg1 ve tevazu dilinin kullanılması gerekmektedir (Gazzâlî, 1438/2017: 69-70).

Gazzâlî, kișilere insanların tamamı özellikle de âlimler hakkında hüsn-ü zanda bulunmalarını, mümkün oldukça âlimlerin sözlerini anlamaya çalışmalarını tavsiye etmektedir. Yukarıda da ifade edildiği gibi o, kişi şayet âlimlerin sözlerini anlamıyorsa kusuru onlarda değil kendisinde aramayı önermektedir. Gazzâlî, mukallide kendi mezheb imamına tabi olmasını ve diğer imamlar hakkında sükût etmesini telkin etmektedir. Ancak müçtehid konumunda olan kişilerin de kendi zann-1 galip görüşüne göre hareket etmelerini, kendilerinin de hata yapma ihtimalleri bulunduğunu kabul etmelerini dolayısıyla karşı1 görüşlere yönelik sert tutum takınmamalarını tavsiye etmektedir (Gazzâlî, 1438/2017: 66-67.).

\section{Sonuç}

Gazzâlî’nin yapılan eleştirinin kabulü ve reddi hususunda eleştirinin farklı yönlerini dikkate alarak bir tavır ortaya koyduğu görülmektedir. Gazzâlî, eleştiri kültürünü temel mantıkî kurallar üzerine bina etmektedir. O, eleştiriyi ne topyekûn reddetmekte ne de kabul etmektedir. O, ilmî normlara ve ahlakî kurallara riayet edilerek hakikatin elde etme düşüncesiyle yapılan eleştiriyi kabul etmektedir. Gazzâlî, buna mukabil insan onurunu zedeleyen, çekememezliğe, insanlara karşı üstünlük taslamaya, kine, giybete, tezkiye-i nefse, ikiyüzlülüğe, riyaya ve yarardan ziyade zarara neden olan eleştiriyi de reddetmektedir. Gazzâlî, eleştiride hakkı izhâr etme arzusunu merkeze almaktadır. Ona göre eleştiride güdülen temel amaç, hakkı ortaya çıkarmak ve doğruyu tespit etmektir.

Gazzâlî'nin el-Menhûl adlı eserinde Ebû Hanife'ye ve İmâm Mâlik'e yönelik eleştirileri katı ve sert olduğu görülmektedir. Söz konusu sertliğin de İmâmü'l-Haremeyn el-Cüveynî'nin etkisinde kalma, ilmî çevredeki taassup atmosferinin oluşturduğu tepki, ilmî ve fikrî tekâmülden önceki durumla alakalı oluşu gibi birçok farklı nedenden kaynaklandığını söylemek mümkündür. Ancak bu sebeplerden daha önemlisi onun hakikatin ortaya çıkması için gösterdiği çabadır. Gazzâlı̂’nin eleştiri anlayışında en önemli nokta, Kur'an ve Sünnetin meramının ortaya çıkması ve günün sorunlarının Kur'ân ve Sünnete yer alan ilkeler 1şı̆̆ında çözülmesidir. O bunun için kendi dönemindeki pek çok âliminin yanlış gördüğü düşünce ve görüşünü eleştirmekten geri durmamıştır. Ancak o, ilgili konuda bilgi verdikten ve delil getirdikten sonra eleştirilerini sıralamıştır. $\mathrm{Bu}$ durum onun bilgi ve delili eleştiri anlayışın ön şartı olarak kabul gördüğüne yorumlamak mümkündür.

Gazzâlî el-Menhûl adlı eserinde imamlara yönelik eleștirileri sert olsa da İhyâu 'ulûmi'd-dîn gibi daha sonra kaleme aldığı eserlerinde imamlara yönelik olumlu tavır sergilemekte ve onların meziyetlerini anlatmaktadır. O, 
İhyâu 'ulûmi'd-dîn'de mezheb imamlarından söz ederken âbid, zâhid gibi onların ortak özelliklerinden bahsederek övmektedir. Gazzâlî, mezheb imamlarını sadece övmekle yetinmemekte hatta onların görüşleri kendisine ters düşen kişilere onları eleştirmekten kaçınmalarını ve kusuru kendilerinde aramalarını dahası onlar hakkında hüsn-ü zanda bulunmalarını tavsiye etmektedir.

\section{Kaynakça}

Afîfî, Muhammed Sâdık. (1400/1980) el-Mucteme'u’lİslâmî ve usûlu'l-hukm. Kahire: Dâru'l-İ'tisâm.

Aynî, Ebû Muhammed Bedruddîn Mahmûd b. Ahmed. (1420/2000) el-Binâye şerhu'l-Hidâye. Beyrut: Dâru'lKutubi'l-'İlmiyye.

Beyhakî, Ebû Bekr Ahmed b. el-Hüseyn. (1414/1994). esSünenü'l-Kübrâ. (I-XI) thk. Muhammed Abdulkâdir 'Atâ. Beyrut: Dâru'l-Kutubi'l-'İlmiyye.

Bilgin, A. (2019). Anlam Değişmeleri Bağlamında "Eleştiri” Kavramının Eleştirisi. M. Aytepe (Ed.) İslam Düşüncesinde Eleştiri Kültürü ve Tahammül Ahlakı (I/45-53), İstanbul: Ensar Yayınları.

Buğda, S. (2020). Fıkıh Usûlü Geleneğinde Münâzara (Ebü'l-Velîd el-Bâcî'nin el-Minhâc fì Tertîbi'l-Hicâc Eseri Bağlamında), Pamukkale Üniversitesi Ilahiyat Fakültesi Dergisi, Cilt 7, Say1 2, 1745-1773.

Buhârî, Ebû Abdullâh Muhammed b. İsmâîl. (1422/2001). Câmi 'u's-Sahîh. I-IX. thk. Muhammed Zuheyr b. Nâsır. b.y.: Dâru Tavki'n-Ncât.

Cessâs, Ahmed b. Alî Ebû Bekr er-Râzî. (1415/1994). Ahkâmu'l-Kur'ân. I-III. thk. Abdusselâm Muhammed Alî Şâhîn. Beyrut: Dâru'l-Kutubi'l-'İlmiyye.

Cüveynî, İmâmü'l-Haremeyn Ebü’l-Meâlî. (1418/1997). elBurhân fî̀ Usûli'l-Fıkh. I-II. thk. Abdülazîm ed-Dîb. Mansûriyye: Dâru'l-Vefâ.

Cüveynî, İmâmü'l-Haremeyn Ebü'l-Meâlî. (1418/1997). Ğyâsü'l-ümem fî̀t-tiyâsi'z-zulem. thk. Abdülazîm edDîb. Mansûriyye: Dâru'l-Vefâ.

Ebû Dâvûd, Süleymân b. el-Eş‘as. (1430/2009). es-Sünen. I-VII. thk. Şu'ayb el-Arnaût - Muhammed Kâmil. Beyrut: Dâru'r-Risâleti'l-İlmiyye.

Ebû Dâvûd Süleymân b. el-Eş‘as. (1414/1993). ez-Zühd. thk. Ebû Temâm Yâsir b. İbrâhîm vd. Halvân: Dâru'lMişkât.

Eşit, D. (2013). “Gazzâlî'nin Ebû Hanîfe Eleştirisi”. Ümit Güneş (Ed.) II. Türkiye Lisansüstü Çalışmalar Kongresi Bildiriler Kitabl. (987-997). İstanbul: Star Ajans Matbaacilık.

Eşit, Y. (2019). Kavleyn Literatürü Bağlamında Şafî̀ Savunusu. Ankara: Fecr Yayınları.

Gazzâlî, Hüccetü'l-İslâm Ebû Hâmid. (1431/2010). Eyuhe'l-veled. thk. Ali Muhyiddîn Ali Karadâğî. Beyrut: Dâru'l-Beşâiri'l-İslâmiyye.

Gazzâlî, Hüccetü’l-İslâm Ebû Hâmid. (1438/2017). Hakîkatu'l-kavleyn. Kuveyt: Esfâr.
Gazzâlî, Hüccetü'l-İslâm Ebû Hâmid. (ts.a). İhyâu 'ulûmi'd-dîn. Beyrut: Dâru'l-Ma'rife.

Gazzâlî, Hüccetü'l-İslâm Ebû Hâmid. (ts.b). el-Menhûl min ta 'lîkâti'l-usûl. thk. Muhammed Hasan Heyto. Beyrut: Dâru'l-Fikr.

Gazzâlî, Hüccetü'l-İslâm Ebû Hâmid. (1414/1991). elMunkiz mine'd-dalâle. Beyrut: Müessesetu'l-Kutubi'sSekâfiyye.

Gazzâlî, Hüccetü'l-İslâm Ebû Hâmid. (1423/2004). elMuntahal fi'l-cedel. thk. Ali Abdulazîz el-Umeyrînî. Riyad: Dâru'l-Verrâk.

Gazzâlî, Hüccetü'l-İslâm Ebû Hâmid. (1417/1997). elMustasfâ min 'Ilmi'l-Usûl. I-II. thk. Muhammed Süleymân el-Eşkar. Beyrut: Müessesetu'r-Risâle.

Gazzâlî, Hüccetü'l-İslâm Ebû Hâmid. (1390/1971). Şifâu'lğalîl fi beyân'ş-şubehi ve'l-muhîli ve mesâliki't-ta'lîl. thk. Hamed el-Kebîsî. Bağdat: Mektebetu'l-İrşâd.

Gazzâlî, Hüccetü'l-İslâm Ebû Hâmid. (1439-2018). Tahsînu'l-Meâhiz. I-IV. thk. Abdulhamîd b. Abdullâh b. Nasır el-Muclî - Muhammed b. Alî b. Semhân Musfir. Kuveyt: Mektebetu'l-İmâmi'z-Zehebî.

Gülaçar, İ. (2019). Gazzâlî’de Eleştirel Yöntem -El-Munkiz Mine'ddalâl Örneği. M. Aytepe (Ed.) İslam Düşüncesinde Eleştiri Kültürü ve Tahammül Ahlakı (III/503-511), İstanbul: Ensar Yayınları.

Haskefî, Alâuddîn Muhammed b. Alî b. Muhammed. (1423/2002). ed-Dürrü'l-muhtâr şerhu Tenvîri'l-ebsâr ve câmi 'i'l-bihâr, thk. Abdülmün'im Halîl İbrâhîm. Beyrut: Dâru'l-Kutubi'l-'İlmiyye.

İbnü'l-Hümâm, Kemâluddîn Muhammed. (1405/1985). Şerhu Fethi'l-Kadîr. I-X. thk. Abdurrezzâk Gâlib elMehdî, (Beyrut: Dâru'l-Kutubi'l-‘'̇lmiyye.

Karasu, T. (2019) Din Eğitiminde Eleştirel Düşünme ve Eleştiri. M. Aytepe (Ed.) İslam Düşüncesinde Eleştiri Kültürü ve Tahammül Ahlakl (I/443-456), İstanbul: Ensar Yayınları.

Kâsânî, Alâuddîn Ebû Bekr. (1406/1986). Bedâ'i'u'ssanâ'i' fî tertîbi'ş-şerâ'í. I-VII. Beyrut: Dâru'lKutubi'l-'İlmiyye.

Korkut, R. (2019). F1kıh Düşüncesinde Münazara Sistematiği (Hatip Bağdâdî'nin el-Fakîh ve'lMütefakkih Esrinin Bağlamında), Bingöl Üniversitesi Ilahiyat Fakültesi Dergisi, Sayı 14, 79-97.

Muttakî el-Hindî, Alî b. Husâmuddîn. (1401/1981). Kenzü'l- 'ummâl fì süneni'l-akvâl ve'l-ef'âl. thk. Bekrî Heyânî - Safvve es-Sekâ. b.y.: Müessesetu'r-Risâle.

Müslim, Ebü'l-Hüseyin Müslim b. el-Haccâc el-Kuşeyrî. (ts.). el-Câmi 'u's-sahîh. I-V. nşr. Muhammed Fuâd Abdulbâkî. Beyrut: Dâru İhyâi’t-Türâsi'l-'Arabî.

Sen'ânî, Muhammed b. İsmâ‘îl. (1405/1985). İrşâdu'nnukkâd ilâ teysîri'l-ictihâd. thk. Selâhaddîn Makbûl Ahmed. Kuveyt: ed-Dâru's Selefiyye.

Yıldız, R. (2019). Eleştiri Kültürü ve Tahammül Ahlakına Fıkhî Yaklaşım. M. Aytepe (Ed.) İslam Düşüncesinde 
Buğda, S. / Anemon Muş Alparslan Üniversitesi Sosyal Bilimler Dergisi, 20219 (IDEKTA) 161-168 168

Eleştiri Kültürü ve Tahammül Ahlakı (III/387-401),

İstanbul: Ensar Yayınları. 


\section{Extended Abstract}

Criticism among the fiqhi madhhabs started with the formation of the madhhabs and have continued so far. Therefore, fiqhi madhhabs have been subject to criticism both during and after their institutionalization process. The imams of madhhabs have been exposed to criticism much more than the faqihs who followed their madhhabs as they were the founders. All mujtahids and faqihs, especially the founding imams, defended their righteousness in their istinbat and ijtihad and criticized those who acted as mukhalifs. For this reason, the effort to defend what is right and reject what is wrong made criticism inevitable. At this point, al-Ghazali (d. 505/1111), one of the scholars of the fifth century Hijri, was not exempt from this attitude. He also criticized some madhhabs/sects and their practices in his works for some reasons. This attitude of his caused criticism of him and Imam Al Shafi'i (d. 204/820) whom he followed. It is controversial that some of the alleged views of Al-Ghazali in his work Al-Mankhul especially on Abu Hanifa (d.150/767) and Imam Malik (d.179/795) overlap with the criticism style he exhibits in his later works or the attitude he shows while criticizing the madhhab imams.

Regarding the acceptance and rejection of criticism Ghazali takes different aspects of criticism into account such as the method, manners, nature, purpose, and competence of the person who criticizes. In his ideal Ghazali builds the culture of criticism on basic logical rules. Ghazali neither rejects nor accepts the process criticism as a whole. He accepts the criticism which made with the idea of obtaining the truth by complying with scientific norms and moral rules. On the other hand, al-Ghazali rejects criticism that harms human dignity, causes envy, superiority towards other people, hatred, backbiting, hypocrisy and harm. Ghazali centers the desire to reveal the truth in criticism. According to him, the main purpose pursued in criticism is the ideal of revealing the right and determining the truth.

Ghazali states that one should not be afraid of anyone's condemnation in accepting the right. He puts forward this idea by taking into account the principle that "the right cannot be abandoned at the cost of avoiding the rebuke of friends". According to al-Ghazali, regardless of a person's ideas and thoughts, madhhab and disposition, what is right must be accepted no matter by whose words it is said. According to Ghazali, the person who comes up with criticism must be a mujtahid or be at a level to issue a fatwa with his own opinion. However, people who are not at the level of mujtahid should criticize by abiding the imam of the madhhab they belong to.

It is a fact that the criticism styles and courage of people while criticizing differ substantially before and after scientific improvement. In addition, it is possible to say that the environment and different conditions in which the criticism is made have an effect on the criticism style of the person. The opponent's style of criticism can also be considered as an important factor in the dose of criticism. In this context, it is seen that Ghazali's criticisms of $\mathrm{Abu}$ Hanifa and Imam Malik in his work al-Manhûl are rigid and harsh. It is possible to say that the said harshness stems from many different reasons, such as being under the influence of Imâmü'l-Haremeyn el-Cüveynî, the atmosphere of bigotry in the scientific environment, and that Ghazali being early on the scientific and intellectual improvement. The most important point in al-Ghazali's understanding of criticism is to reveal the Shari's aim in the "Text"s. For this reason, he did not refrain from criticizing the thoughts and views that he saw as wrong considering the aim of Shari. However, he listed his criticisms not by itself but rather after giving the information and providing evidence on the relevant issue. This situation can be interpreted that in Ghazali's understanding knowledge and evidence is accepted as prerequisite for making criticism.

Although Gazzâlî made harsh criticisms towards imâms in his earlier work al-Menhûl, in his later works such as İhyâu 'ulûmi'd-Dîn, he exhibits a much more positive attitude towards imâms and describes their merits. While talking about the imâms of the madhhabs in İhyâu 'ulûmi'd-Dîn, he praises them by mentioning their common characteristics such as âbid and zâhid. Ghazali not only praises the imâms of the madhhab, but also advises those whose views are contrary to them to avoid criticizing them, to have good thoughts about them, and moreover, to look for the fault in them regarding their contradicting views. 